\title{
Aluminum-Induced Conformational Changes of $\beta$ - Amyloid Protein and the Pathogenesis of Alzheimer's Disease
}

\author{
Masahiro Kawahara* \\ Department of Analytical Chemistry, School of Pharmaceutical Sciences, Kyushu University of Health and Welfare, 1714-1 Yoshino- \\ cho, Nobeoka-city, Miyazaki 882-8508, Japan
}

(Received June 9, 2003)

\begin{abstract}
Aggregation and subsequent conformational change of Alzheimer's $\beta$-amyloid protein $(\mathrm{A} \beta \mathrm{P})$ enhance its neurotoxicity. Therefore, factors that inhibit or promote conformational changes of $\mathrm{A} \beta \mathrm{P}$ play crucial roles in the pathogenesis of Alzheimer's disease (AD). Moreover, recent studies have suggested that a common mechanism is based on the diverse diseases termed "conformational diseases" including neurodegenerative diseases such as AD, prion diseases, Parkinson's disease, and Huntington's disease. These diseases share similarity in the formation of $\beta$-sheet containing amyloid fibrils by disease-related proteins and the introduction of apoptotic degeneration. Aluminum, an environmental risk factor for $\mathrm{AD}$, is a widely used cross-linker that causes conformational changes of $\mathrm{A} \beta \mathrm{P}$ and other proteins. This report reviews and discusses characteristics of aluminum-induced conformational changes of $\mathrm{A} \beta \mathrm{P}$ and their implication in pathogenesis of AD. Taking together our results and those of numerous other studies, we hypothesize that aluminum-induced conformational changes enhance the neurotoxicity of $\mathrm{A} \beta \mathrm{P}$ and lead to development of AD.
\end{abstract}

Key words — conformational disease, prion disease, aggregation, neurotoxicity, calcium homeostasis

\section{INTRODUCTION}

Alzheimer's disease (AD) is a senile type dementia characterized by abnormal deposits of senile plaques and neurofibrillary tangles (NFTs) in patient's brain. The major component of senile plaque is $\beta$-amyloid protein $(\mathrm{A} \beta \mathrm{P}) . \mathrm{A} \beta \mathrm{P}$ is a small peptide with 39-43 amino acid residues derived from the proteolytic cleavage of a large precursor protein (amyloid precursor protein; APP). Yankner et al. reported that the first 40 amino acid residues of $\mathrm{A} \beta \mathrm{P}$ $(\mathrm{A} \beta \mathrm{P}[1-40])$ caused the death of cultured rat hippocampal neurons. ${ }^{1)}$ Recent genetic studies revealed that the 21st chromosome of familial Alzheimer's patients possesses a single point mutation in the codon for APP. ${ }^{2)}$ These evidences support the idea that accumulation of $\mathrm{A} \beta \mathrm{P}$ and consequent neuro-

\footnotetext{
*To whom all correspondence should be addressed: Department of Analytical Chemistry, School of Pharmaceutical Sciences, Kyushu University of Health and Welfare, 1714-1 Yoshino-cho, Nobeoka-city, Miyazaki 882-8508, Japan. Tel.: +81-982-235706; Fax: +81-982-23-5708; E-mail: kawamasa@phoenix.ac.jp
}

degeneration caused by $\mathrm{A} \beta \mathrm{P}$ may be based on the molecular mechanism of AD. ${ }^{3)}$ However, $\mathrm{A} \beta \mathrm{P}$ has an intrinsic tendency to polymerize and form insoluble aggregates with $\beta$-pleated sheet structures in an aqueous solution. There is increasing evidence that aggregation and subsequent conformational changes of $\mathrm{A} \beta \mathrm{P}$ enhance its neurotoxicity. Simmons et al. demonstrated that the ratio of $\beta$-sheet structures of $\mathrm{A} \beta \mathrm{P}[1-40]$ was correlated with its neurotoxicity. ${ }^{4)} \mathrm{A}$ longer peptide variant $(\mathrm{A} \beta \mathrm{P}[1-42])$ has the characteristic of immediate polymerization compared to $\mathrm{A} \beta \mathrm{P}[1-40]$ : it enhances aggregation of $\mathrm{A} \beta \mathrm{P}[1-40] .{ }^{5)}$

Considering that $\mathrm{A} \beta \mathrm{P}$ exists in cerebrospinal fluid (CSF) even during childhood and that its concentration is not elevated in the CSF of $\mathrm{AD}$ patients compared with that in controls, ${ }^{6}$ it is probable that factors that promote or inhibit aggregation of $\mathrm{A} \beta \mathrm{P}$ play crucial roles in its neurotoxicity (Fig. 1). As such inhibitory factors, transthyretin, a protein colocalized with $\mathrm{A} \beta \mathrm{P}$ in CSF, was reported to bind to $\mathrm{A} \beta \mathrm{P}$ and thereby inhibit its aggregation. ${ }^{7)}$ Non-aggregated $\mathrm{A} \beta \mathrm{P}$ 

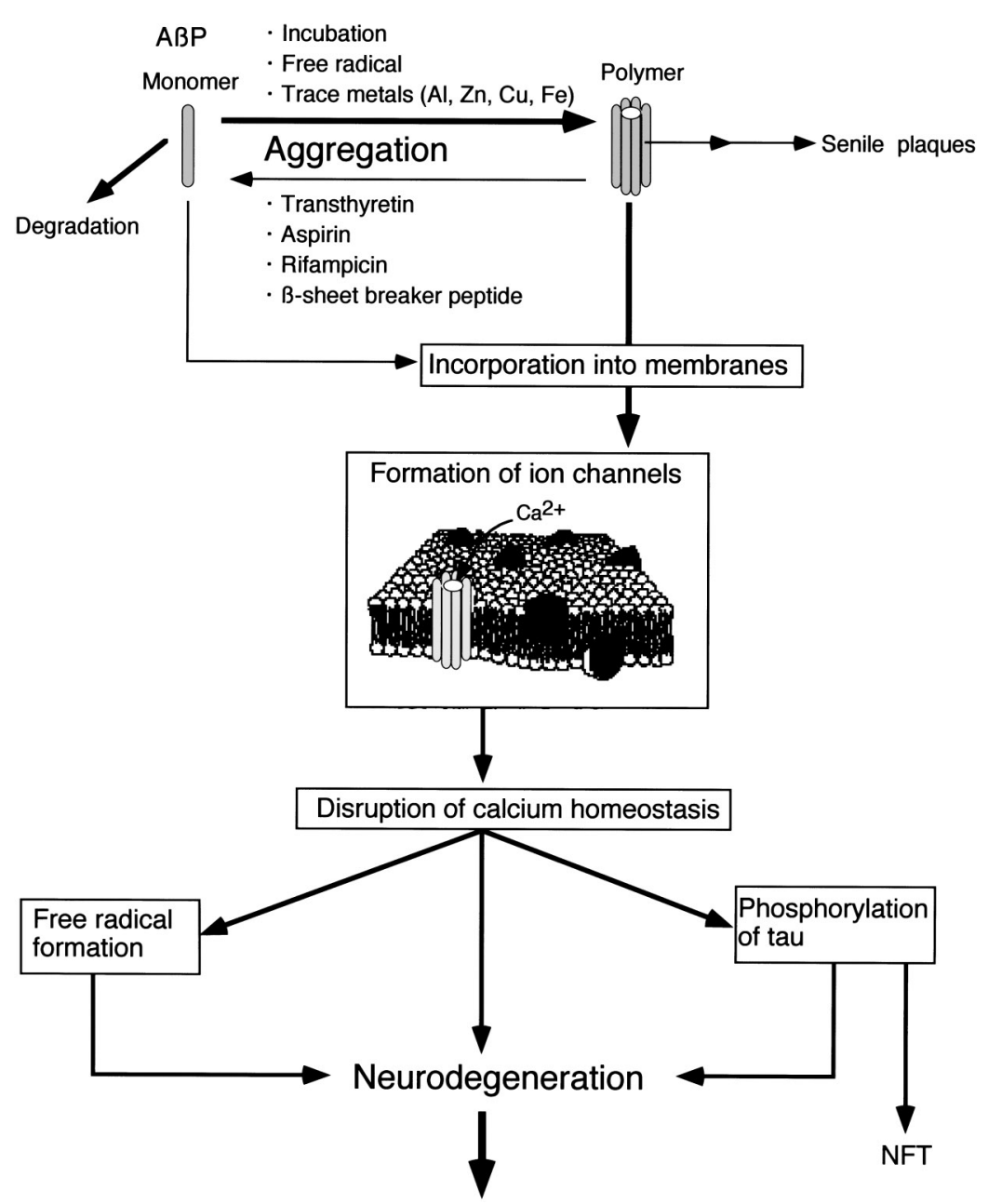

Alzheimer's disease

Fig. 1. Hypothesis Regarding the Metal-Induced Aggregation of $\mathrm{A} \beta \mathrm{P}$ in the Pathogenesis of Alzheimer's Disease

Secreted $\mathrm{A} \beta \mathrm{P}$ is rapidly degraded by proteases in general. However, in the presence of factors that promote aggregation, $\mathrm{A} \beta \mathrm{P}$ forms insoluble and protease-resistant polymers and accumulates in the brain. $\mathrm{A} \beta \mathrm{P}$ can incorporate into membranes directly, where it forms "amyloid channels" and disrupts calcium homeostasis. The channels comprise peptide oligomers; therefore, polymerization of A $\beta \mathrm{P}$ enhances the provability of forming channels. The abnormal influx of calcium through the amyloid channels can trigger various neurodegenerative pathways such as the phosphorylation of tau and the generation of free radicals, leading to neuronal death and $\mathrm{AD}$ pathogenesis. The abnormal calcium influx through amyloid channels causes neuronal death and may lead ultimately to AD.

is inferred to be degraded by the usual proteolytic pathways. Several non-steroidal anti-inflammatory drugs (NSAIDs) such as aspirin or ibuprofen were reported to inhibit the aggregation of $\mathrm{A} \beta \mathrm{P}{ }^{8)}$ Recent epidemiological studies have suggested that these NSAIDs reduce the relative risk of AD. ${ }^{9)}$ Rifampicin (an antibiotic), or $\beta$-sheet breaker peptide (a peptide analogue of $\mathrm{A} \beta \mathrm{P}$ ) were also reported to inhibit polymerization of $\mathrm{A} \beta \mathrm{P}$ and are considered to be candidates of drugs for $\mathrm{AD}$ treatment. ${ }^{10,11)}$ On the other hand, there are factors that promote the polymerization of $\mathrm{A} \beta \mathrm{P}$ and thereby enhance the risk of $\mathrm{AD}$. As such factors, free radicals, ${ }^{12)}$ incubation at $37^{\circ} \mathrm{C},{ }^{13)}$ and trace metals have been reported. Among them, aluminum (Al) has attracted attention for its possible implication in AD based on numerous epidemiological and biochemical studies. ${ }^{14)}$

\section{Effects of Aluminum on Conformational Changes of $\mathbf{A} \boldsymbol{\beta} P$}

The aluminum ion $\left(\mathrm{Al}^{3+}\right)$ possesses several peculiar chemical characteristics. $\left.{ }^{15}\right) \mathrm{Al}^{3+}$ favors oxygendonor ligands, especially if they are negatively charged. Inorganic or organic phosphates, carboxylate, deprotonated hydroxy groups are strong $\mathrm{Al}^{3+}$ binders. Furthermore, the ligand-exchange rate for $\mathrm{Al}^{3+}$ is very low compared to other essential metals. For example, $\mathrm{Al}^{3+}$ is reported to be $10^{7}$ more effec- 

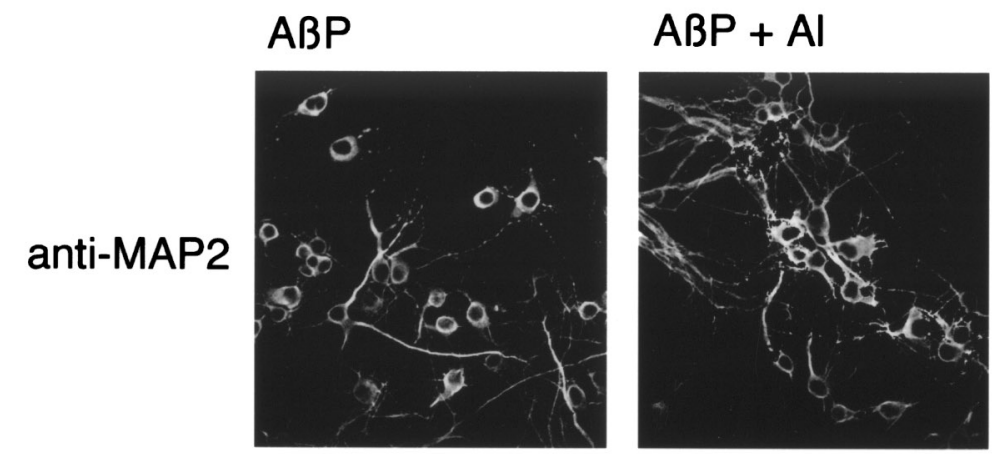

$A B P+Z n$
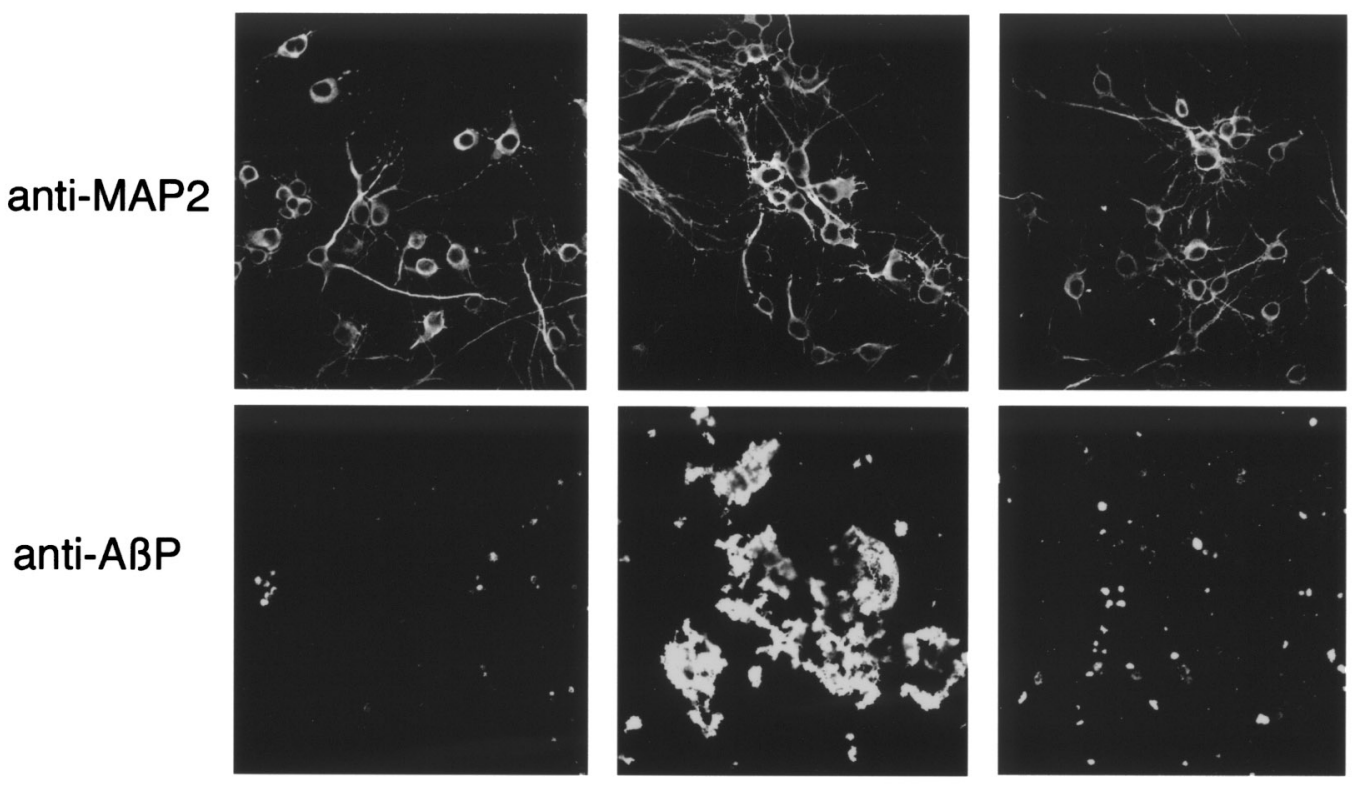

Fig. 2. Deposition of Al-Aggregated $\mathrm{A} \beta \mathrm{P}$ on Cultured Neurons

Solutions of $\mathrm{A} \beta \mathrm{P}[1-40]$ pre-incubated at $37^{\circ} \mathrm{C}$ for $24 \mathrm{hr}, \mathrm{A} \beta \mathrm{P}[1-40]$ pretreated with $\mathrm{AlCl}_{3} 1 \mathrm{mM}$, and $\mathrm{A} \beta \mathrm{P}[1-40]$ pretreated with $\mathrm{ZnCl}_{2} 1 \mathrm{mM}$ were applied to cultured rat cortical neurons. After 4 days, cultured neurons were washed out, double-immunostained with an antibody to A $\beta \mathrm{P}$ and an antibody to MAP2, and observed under a confocal laser scanning microscope. Bar represents $50 \mu \mathrm{m}$.

tive than $\mathrm{Mg}^{2+}$ in the binding and polymerization of tubulin. Thus, biological processes involving rapid $\mathrm{Ca}^{2+}$ exchange could be inhibited by substitution of the $10^{8}$-fold slower $\mathrm{Al}^{3+}$. Also, $\mathrm{Al}^{3+}$ shares similarities with iron ion $\left(\mathrm{Fe}^{3+}\right)$ and binds to $\mathrm{Fe}^{3+}$-binding proteins such as transferrin. These chemical characteristics of $\mathrm{Al}^{3+}$ make it useless in metal-engaged biological reactions, and therefore, $\mathrm{Al}$ is not essential in biological functions. $\mathrm{Al}$ is a widely used crosslinker as a tanning agent for leathers.

There are reports of $\mathrm{Al}^{3+}$-induced conformational change of calmodulin. ${ }^{16)}$ Strong binding of $\mathrm{Al}^{3+}$ to phosphorylated amino acids promotes self-aggregation of highly phosphorylated cytoskeletal proteins such as neurofilament or microtubule-associated proteins (MAPs). ${ }^{17,18)} \mathrm{Al}^{3+}$ also binds to transferrin and changes its conformation. Exley et al. demonstrated that $\mathrm{Al}$ caused conformational changes of $\mathrm{A} \beta \mathrm{P}[1-40]$ using circular dichroism spectroscopy. ${ }^{19)}$ Mantyh et al. reported that $\mathrm{Al}, \mathrm{Fe}$ and zinc (Zn) promoted aggregation of ${ }^{125}$ I-labeled $\mathrm{A} \beta \mathrm{P}[1-40] .{ }^{20)} \mathrm{We}$ have developed a system for the investigation of $\mathrm{A} \beta \mathrm{P}$ polymerization involving immunoblotting and precipitation. Using that method, we found that $\mathrm{Al}$ enhances polymerization of $\mathrm{A} \beta \mathrm{P}[1-40]$ and forms sodium dodecyl sulfate (SDS)-stable oligomers in vitro. ${ }^{21,22)}$ Aggregated $\mathrm{A} \beta \mathrm{P}[1-40]$ was re-dissolved by adding deferoxamine (DFO), a chelator of Al. Polymerization induced by $\mathrm{Al}$ was more marked than that by other metals including $\mathrm{Zn}, \mathrm{Fe}, \mathrm{Cu}$, and cadmium (Cd). Furthermore, Al-aggregated A $\beta$ Ps tightly bound to the surface of cultured neurons and formed fibrillar deposits, whereas $\mathrm{Zn}$-aggregated $\mathrm{A} \beta \mathrm{Ps}$ were rarely observed on the surface of cultured neurons after 4 days (Fig. 2). ${ }^{23)}$ These results suggest that $\mathrm{Al}$ aggregated $\mathrm{A} \beta \mathrm{Ps}$ have strong affinity to membrane surfaces and are scarcely degraded by proteases. Although $\mathrm{Al}^{3+}$ firmly binds to adenosine triphosphate (ATP), ATP enhanced Al-induced $\beta$-sheet formation of $\mathrm{A} \beta \mathrm{P}^{24)}$ Meanwhile, acetyl salicylic acid (aspirin) reduced $\mathrm{Al}$-induced aggregation of $\mathrm{A} \beta \mathrm{P}^{8)}$

Bush et al. argued that $\mathrm{Zn}^{2+}$ in the range similar to that in CSF was sufficient to cause aggregation of $\mathrm{A} \beta \mathrm{P}^{25)}$ The binding of $\mathrm{Cu}^{2+}$ to $\mathrm{A} \beta \mathrm{P}$ induced aggregation and caused rise to reactive oxygen species. ${ }^{26)}$ Furthermore, APP possesses copper/zinc binding sites in its amino-terminal domain and in the $\mathrm{A} \beta \mathrm{P}$ domain. ${ }^{27)}$ However, a large amount of $\mathrm{Zn}$ exists in the brain and the high concentration (up to $300 \mu \mathrm{M}$ ) of $\mathrm{Zn}^{2+}$ is secreted to synaptic clefts after neuronal excitation. ${ }^{28)}$ Thus, the implication of $\mathrm{Zn}$-induced $\mathrm{A} \beta \mathrm{P}$ polymerization in the etiology of $\mathrm{AD}$ remains elusive.

Abnormal deposits of $\mathrm{A} \beta \mathrm{P}$ (senile plaques) are 
observed in aged humans, monkeys, and dogs, but rarely found in rats and mice. Although the sequences of rodent APP are approximately $96 \%$ similar to human APP, three amino acid substitutions are found in the $\mathrm{A} \beta \mathrm{P}$ region of rodents: $\mathrm{Arg}_{5} \rightarrow \mathrm{Gly}$, $\mathrm{Tyr}_{10} \rightarrow$ Phe, and $\mathrm{His}_{13} \rightarrow$ Arg. ${ }^{29)}$ All of these residues have the ability to bind to metals. The Tyr and Arg residues of transferrin are essential for its binding to $\mathrm{Fe}^{3+}$. Aggregation of $\mathrm{A} \beta \mathrm{P}$ induced by $\mathrm{Zn}$ or $\mathrm{Cu}$ was abolished by the methylation of its His residues. ${ }^{27)}$ Therefore, it is probable that these metalbinding amino acid residues are crucial for metalinduced polymerization of $\mathrm{A} \beta \mathrm{P}$; their substitutions might explain the lack of amyloid deposits in rodent brains. We synthesized mutated $\mathrm{A} \beta \mathrm{P}$ substituted these metal-binding amino acid residues to investigate the mechanism of $\mathrm{Al}^{3+}$ binding to $\mathrm{A} \beta \mathrm{P}$. We found that $\mathrm{Tyr}_{10}$ is essential for Al-induced polymerization of $\mathrm{A} \beta \mathrm{P}^{30)}$

\section{Effects of Aluminum on Other Disease-Related Proteins}

Diverse human disorders are thought to arise from the misfolding and aggregation of an underlying protein. Those diseases include neurodegenerative disorders such as AD, Parkinson's disease, prion encephalopathies, and triplet repeat disease (including Huntington's disease), as well as cystic fibrosis and systemic amyloidosis. Carrell and Lomas proposed the concept of "conformational disease," which may explain the same mechanism of development of these diseases. ${ }^{31)}$ The underlying diseaserelated proteins exhibit similarities in terms of formation of amyloid fibrils with $\beta$-pleated sheet structures and the introduction of apoptotic degeneration. Aggregation and fibrillation of $\alpha$-synuclein has been implicated in the formation of abnormal inclusions (Lewy bodies) and has been considered as a key step in the etiology of Parkinson's disease and several other neurodegenerative disorders (dementia with Lewy bodies; DLB). Uversky et al. found that $\mathrm{Al}$ and other metals markedly promoted the aggregation of $\alpha$-synuclein. ${ }^{32)}$ Furthermore, Al promotes aggregation of $\mathrm{APP}^{33)}$ and tau protein, ${ }^{34)}$ which is a major component of Alzheimer's NFTs.

\section{Mechanism of A $\beta$ P Neurotoxicity}

The precise mechanism underlying $\mathrm{A} \beta \mathrm{P}$-induced neuronal death remains elusive. However, we have found that $\mathrm{A} \beta \mathrm{P}[1-40]$ directly incorporates into neuronal membranes and forms cation-selective (includ- ing $\mathrm{Ca}^{2+}$ ) ion channels. ${ }^{35)}$ Characteristics of these amyloid channels ("pores") formed on neuronal membranes were quite similar to those first reported on artificial planar membranes. ${ }^{36,37)}$ Conformational analysis of $\mathrm{A} \beta \mathrm{P}$ in membranes suggests that the 5to 8-mers of $\mathrm{A} \beta \mathrm{P}[1-40]$ oligomerize and form a channel structure across the membrane. ${ }^{38)} \mathrm{A} \beta \mathrm{P}[1-$ 42] or other amyloidogenic peptides such as prion protein fragment in prion diseases, human islet amyloid peptide (amylin) in type 2 diabetes mellitus, polyglutamin in triplet repeat disease, and $\alpha$ synuclein in Parkinson's disease were reported to form channels on artificial lipid bilayers. ${ }^{39)}$ Table 1 summarizes the characteristics of amyloidogenic peptides. Although these peptides have no similarities in their primary sequences, all peptides form amyloid fibril structures with $\beta$-pleated sheets, possess cytotoxicity, and have ability to form ion channels. Meanwhile, although the sequence of rodent amylin is approximately $95 \%$ similar to human amylin, rat amylin has no ability to form amyloid fibrils, to cause cytotoxicity, or to form ion channels.

Abnormal influx of $\mathrm{Ca}^{2+}$ into neurons through these "amyloid channels" is inferred to trigger various neurodegenerative processes and apoptotic pathways. In fact, we have also demonstrated that $\mathrm{A} \beta \mathrm{P}$ causes an acute increase of intracellular calcium level of neuronal cells and consequent cell death as expected. Furthermore, other amyloidogenic peptides including prion protein fragment and human islet amyloid peptide caused disruption of calcium homeostasis. ${ }^{40)}$

In light of these facts, we formed the following hypothesis about the polymerization of $\mathrm{A} \beta \mathrm{P}$ and Alzheimer's pathogenesis: Once channels were formed on neuronal membranes, the abnormal influx of $\left[\mathrm{Ca}^{2+}\right]$ triggers various neurodegenerative pathways, and finally leads to AD. This hypothesis coincides with the idea that amyloid fibers form cylindrical nanotubes constructed with $\beta$-sheet oligomers as shown by $\mathrm{X}$-ray crystallography and electron microscope analysis. ${ }^{41}$

\section{CONCLUSION}

Although the link between $\mathrm{Al}$ and $\mathrm{AD}$ has been discussed for several decades, it is still controversial. However, there is increasing evidence that suggests the implication of metals in $\mathrm{AD}$ pathogenesis. 
Table 1. Characteristics of Conformational Disease-Related Protein

\begin{tabular}{|c|c|c|c|c|}
\hline Disease & $\begin{array}{l}\text { Amyloidogenic protein or its fragment } \\
\text { peptide }\end{array}$ & $\begin{array}{c}\beta \text {-sheet } \\
\text { formation }\end{array}$ & $\begin{array}{c}\text { Cyto } \\
\text { toxicity }\end{array}$ & $\begin{array}{l}\text { Channel } \\
\text { formation }\end{array}$ \\
\hline Alzhelmer's disease & $\begin{array}{l}\mathrm{A} \beta \mathrm{P}[1-40] \\
\text { DAEFRHDSGYEVHHQKLVFFAE } \\
\text { DVGSNKGAIIGLMVGGVV }\end{array}$ & + & + & + \\
\hline Prion disease & $\begin{array}{l}\text { PrP106-126 (prion protein fragment) } \\
\text { KTNMKHMAGAAAAGAVVGGLG }\end{array}$ & + & + & + \\
\hline Parkinson's disease & $\begin{array}{l}\text { NAC ( } \alpha \text {-synuclein fragment) } \\
\text { EQVTNVGGAVVTGVTAVAQKTVEGAG } \\
\text { SIAAATGFV }\end{array}$ & + & + & + \\
\hline Triplet repeat disease & $\begin{array}{l}\text { Polyglutamine } \\
\text { QQQQQQ- }\end{array}$ & + & + & + \\
\hline Diabetes mellitus & $\begin{array}{l}\text { Human amylin } \\
\text { KCNTATCATQRLANFLVHSSNN } \\
\text { FGAILSSTNVGSNTY }\end{array}$ & + & + & + \\
\hline & $\begin{array}{l}\text { Rat amylin } \\
\text { KCNTATCATQRLANFLVRSSNN } \\
\text { LGPVLPPTNVGSNTY }\end{array}$ & - & - & - \\
\hline
\end{tabular}

A considerable number of epidemiological studies has indicated an association between $\mathrm{AD}$ and $\mathrm{Al}$ in drinking water. ${ }^{42)}$ Recent studies have suggested that clioquinol (quinoform), a metal chelator, was reported to inhibit accumulation of $\mathrm{A} \beta \mathrm{P}$ and has been examined as a candidate drug for $\mathrm{AD} .{ }^{43)} \mathrm{Heme}$ deficiency induced by aging, iron-deficiency, vitamin B6-deficiency, metals such as lead $(\mathrm{Pb})$ or $\mathrm{Al}$ causes mitochondrial and neuronal dysfunction. ${ }^{44)}$ The polymorphism of the gene encoding transferrin is a risk factor for AD. ${ }^{45)}$ Iron supplement therapy is effective in attenuating the mental condition of AD patients. ${ }^{46)} \mathrm{Al}$ in the diet markedly increased the amount of secreted $\mathrm{A} \beta \mathrm{P}$ in the brains of transgenic mice transfected with the human APP gene; $\mathrm{A} \beta \mathrm{P}$ accumulation was also marked. ${ }^{47)}$ Furthermore, we have reported that $\mathrm{Al}$ influences the functions of brain-derived neurotrophic factor which decreses in AD brain. ${ }^{48)}$ Therefore, it is difficult to deny the implication of $\mathrm{Al}$ in $\mathrm{AD}$ pathogenesis. Our hypothesis suggesting that $\mathrm{Al}$ induces conformational changes of $\mathrm{A} \beta \mathrm{P}$ and enhances the neurotoxicity could explain several unsolved aspects of the relation between $\mathrm{Al}$ and $\mathrm{AD}$.

\section{REFERENCES}

1) Yankner, B. A., Duffy, L. K. and Kirschner, D. A. (1990) Neurotropic and neurotoxic effects of amyloid $\beta$ protein: reversal by tachykinin neuropeptides. Nature (London), 250, 279-282.

2) Goate, A., Chartier-Harlin, M. C., Mullan, M. Brown, J., Crawford, F., Fidani, L., Giuffra, L., Haynes, A., Irving, N. and James, L., et al. (1991) Segregation of a missense mutation in the amyloid precursor protein gene with familial Alzheimer's disease. Nature (London), 349, 704-706.

3) Small, D. H., Mok, S. S. and Bornstein, J. C. (2001) Alzheimer's disease and A $\beta$ toxicity: from top to bottom. Nat. Rev. Neurosci., 2, 595-598.

4) Simmons, L. K., May, P. C., Tomaselli, K. J., Rydel, R. E., Fuson, K. S., Brigham, E. F., Wright, S., Lieberburg, I., Becker, G. W. and Brems, D. N., et al. (1994) Secondary structure of amyloid beta peptide correlates with neurotoxic activity in vitro. Mol. Pharmacol., 45, 373-379.

5) Jarrett, J. T. and Lansbury, P. T., Jr. (1993) Seeding "one-dimensional crystallization" of amyloid: a pathogenic mechanism in Alzheimer's disease and scrapie? Cell, 73, 1055-1058.

6) Fukuyama, R., Mizuno, T., Mori, S., Nakajima, K., Fushiki, S. and Yanagisawa, K. (2000) Agedependent change in the levels of $A \beta 40$ and $A \beta 42$ in cerebrospinal fluid from control subjects, and a decrease in the ratio of $\mathrm{A} \beta 42$ to $\mathrm{A} \beta 40$ level in 
cerebrospinal fluid from Alzheimer's disease patients. Eur. Neurol., 43, 155-160.

7) Schwarzman, A. L., Gregori, L., Vitek, M. P., Lyubski, S., Strittmatter, W. J., Enghilde, J. J., Bhasin, R., Silverman, J., Weisgraber, K. H. and Coyle, P. K., et al. (1994) Transthyretin sequesters amyloid beta protein and prevents amyloid formation. Proc. Natl. Acad. Sci. U.S.A., 91, 83688372.

8) Thomas, T., Nadackal, T. G. and Thomas, K. (2001) Aspirin and non-steroidal anti-inflammatory drugs inhibit amyloid-beta aggregation. Neuroreport, 12, 3263-3267.

9) Veld, B. A., Ruitenberg, A., Hofman, A., Launer, L. J., van Duijn, C. M., Stijnen, T., Breteler, M. M. and Stricker, B. H. (2001) Nonsteroidal anti-inflammatory drugs and the risk of Alzheimer's disease. $N$. Engl. J. Med., 345, 1515-1521.

10) Tomiyama, T., Asano, S., Suwa, Y., Morita, T., Kataoka, K., Mori, H. and Endo, N. (1994) Rifampicin prevents the aggregation and neurotoxicity of amyloid beta protein in vitro. Biochem. Biophys. Res. Commun., 204, 76-83.

11) Permanne, B., Adessi, C., Saborio, G. P., Fraga, S., Frossard, M. J., Van Dorpe, J., Dewachter, I., Banks, W. A., Van Leuven, F. and Soto, C. (2002) Reduction of amyloid load and cerebral damage in a transgenic mouse model of Alzheimer's disease by treatment with a beta-sheet breaker peptide. FASEB. J., 16, 860-862.

12) Hensley, K., Carney, J. M., Mattson, M. P., Aksenova, M., Harris, M., Wu, J. F., Floyd, R. A. and Butterfield, D. A. (1994) A model for $\beta$-amyloid aggregation and neurotoxicity based on free radical generation by the peptide: relevance to Alzheimer disease. Proc. Natl. Acad. Sci. U.S.A., 91, 32703274.

13) Cotman, C. W., Pike, C. J. and Copani, A. (1992) $\beta$ Amyloid neurotoxicity: a discussion of in vitro findings. Neurobiol. Aging, 13, 587-590.

14) Kawahara, M. (2001) Neurotoxicity of aluminum and its implication in neurodegenerative disease. Biomed. Res. Trace Elements, 12, 207-216.

15) Martin, R. B. (1997) Chemistry of aluminum in the central nervous system. In Mineral and Metal Neurotoxicology (Yasui, M., et al., Eds.) CRC Press, New York, pp. 75-81.

16) Siegel, N. and Haug, A. (1983) Aluminum interaction with calmodulin. Evidence for altered structure and function from optical and enzymatic studies. Biochim. Biophys. Acta, 744, 36-45.

17) Diaz-Nido, J. and Avila, J. (1990) Aluminum induces the in vitro aggregation of bovine brain cytoskeletal protein. Neurosci. Lett., 110, 221-226.
18) Hollosi, M., Urge, L., Perczel, A., Kajtar, J., Teplan, I., Otvos, L., Jr. and Fasman, G. D. (1994) Metal ion-induced conformational changes of phosphorylated fragments of human neurofilament (NF-M) protein. J. Mol. Biol., 223, 673-682.

19) Exley, C., Price, N. C., Kelly, S. M. and Birchall, J. D. (1993) An interaction of $\beta$-amyloid with aluminium in vitro. FEBS Lett., 324, 293-295.

20) Mantyh, P. W., Ghilardi, J. R., Rogers, S., DeMaster, E., Allen, C. J., Stimson, E. R. and Maggio, J. E. (1993) Aluminum, iron, and zinc ions promote aggregation of physiological concentrations of $\beta$ amyloid peptide. J. Neurochem., 61, 1171-1174.

21) Kawahara, M., Muramoto, K., Kobayashi, K., Mori, H. and Kuroda, Y. (1994) Aluminum promotes the aggregation of Alzheimer's $\beta$-amyloid protein in vitro. Biochem. Biophys. Res. Commun., 198, 531535.

22) Kuroda, Y. and Kawahara, M. (1994) Aggregation of amyloid $\beta$-protein and its neurotoxicity: enhancement by aluminum and other metals. Tohoku J. Exp. Med., 174, 263-268.

23) Kawahara, M., Kato, M. and Kuroda, Y. (2001) Effects of aluminum on the neurotoxicity of primary cultured neurons and on the aggregation of $\beta$ amyloid protein. Brain Res. Bull., 55, 211-217.

24) Exley, C. (1997) ATP-promoted amyloidosis of an amyloid beta peptide. Neuroreport, 8, 3411-3414.

25) Bush, A. I., Pettingell, W. H., Multhaup, G., d Paradis, M., Vonsattel, J. P., Gusella, J. F., Beyreuther, K., Masters, C. L. and Tanzi, R. E. (1994) Rapid induction of Alzheimer A $\beta$ amyloid formation by zinc. Science, 265, 1464-1467.

26) Atwood, C. S., Moir, R. D., Huang, X., Scarpa, R. C., Bacarra, N. M., Romano, D. M., Hartshorn, M. A., Tanzi, R. E. and Bush, A. I. (1998) Dramatic aggregation of Alzheimer $\mathrm{A} \beta$ by $\mathrm{Cu}(\mathrm{II})$ is induced by conditions representing physiological acidosis. J. Biol. Chem., 273, 12817-12826.

27) Curtain, C. C., Ali, F., Volitakis, I., Cherny, R. A., Norton, R. S., Beyreuther, K., Barrow, C. J., Masters, C. L., Bush, A. I. and Barnham, K. J. (2001) Alzheimer's disease Amyloid- $\beta$ binds copper and zinc to generate an allosterically ordered membrane-penetrating structure containing superoxide dismutase-like subunits. J. Biol. Chem., 276, 2046620473.

28) Frederickson, C. J., Suh, S. W., Silva, D., Frederickson, C. J. and Thompson, R. B. (2000) Importance of zinc in the central nervous system: the zinc-containing neuron. J. Nutr., 130, 1471S$1483 \mathrm{~S}$.

29) Fraser, P. E., Nguyen, J. T., Inouye, H., Surewicz, W. K., Selkoe, D. J., Podlisny, M. B. and Kirschner, 
D. A. (1992) Fibril formation by primate, rodent, and Dutch-hemorrhagic analogues of Alzheimer amyloid beta-protein. Biochemistry, 31, 1071610723.

30) Kawahara, M., Kojima, S., Kato, M., Mori, H., Miura, K. and Kuroda, Y. (1995) Effects of sitespecific mutagenesis on the aggregation of amyloid $\beta$-protein $(\mathrm{A} \beta \mathrm{P})$ : interactions with aluminum. Abst. Soc. Neurosci., 21, 155.

31) Carrell, R. W. and Lomas, D. A. (1997) Conformational disease. Lancet, 350, 134-138.

32) Uversky, V. N., Li, J. and Fink, A. L. (2001) Metaltriggered structural transformations, aggregation, and fibrillation of human alpha-synuclein. A possible molecular link between Parkinson's disease and heavy metal exposure. J. Biol. Chem., 276, 4428444296.

33) Chong, Y. H. and Suh, Y. H. (1995) Aggregation of amyloid precursor proteins by aluminum in vitro. Brain Res., 670, 137-41.

34) Scott, C. W., Fieles, A., Sygowski, L. A. and Caputo, C. B. (1993) Aggregation of tau protein by aluminum. Brain Res., 628, 77-84.

35) Kawahara, M., Arispe, N., Kuroda, Y. and Rojas, E. (1997) Alzheimer's disease amyloid $\beta$-protein forms $\mathrm{Zn}^{2+}$-sensitive, cation-selective channels across excised membrane patches from hypothalamic neurons. Biophys. J., 73, 67-75.

36) Arispe, N., Rojas, E. and Pollard, H. B. (1993) Alzheimer disease amyloid beta protein forms calcium channels in bi-layer membranes: Blockade by tromethamine and aluminum. Proc. Natl. Acad. Sci. U.S.A., 90, 567-571.

37) Arispe, N., Pollard, H. and Rojas, E. (1996) $\mathrm{Zn}^{2+}$ interaction with Alzheimer amyloid beta protein calcium channels. Proc. Natl. Acad. Sci. U.S.A., 93, 1710-1715.

38) Durell, S. R., Guy, H. R., Arispe, N., Rojas, E. and Pollard, H. B. (1994) Theoretical models of the ion channel structure of amyloid $\beta$-protein. Biophys. J., 67, 2137-2145.

39) Kawahara, M. and Kuroda, Y. (2000) Molecular mechanism of neurodegeneration induced by Alzheimer's $\beta$-amyloid protein: channel formation and disruption of calcium homeostasis. Brain Res.
Bull., 53, 389-397.

40) Kawahara, M., Arispe, N., Kuroda, Y. and Rojas, E. (2000) Alzheimer's $\beta$-amyloid, human islet amylin and prion protein fragment evoke intracellular freecalcium elevations by a common mechanism in a hypothalamic GnRH neuronal cell-line. J. Biol. Chem., 275, 14077-14083.

41) Perutz, M. F., Finch, J. T., Berriman, J. and Lesk, A. (2002) Amyloid fibers are water-filled nanotubes. Proc. Natl. Acad. Sci. U.S.A., 99, 5591-5595.

42) Flaten, T. P. (2001) Aluminium as a risk factor in Alzheimer's disease, with emphasis on drinking water. Brain Res. Bull., 55, 187-196.

43) Cherny, R. A., Atwood, C. S., Xilinas, M. E., Gray, D. N., Jones, W. D., McLean, C. A., Barnham, K. J., Volitakis, I., Fraser, F. W., Kim, Y., Huang, X., Goldstein, L. E., Moir, R. D., Lim, J. T., Beyreuther, K., Zheng, H., Tanzi, R. E., Masters, C. L. and Bush, A. I. (2001) Treatment with a copper-zinc chelator markedly and rapidly inhibits $\beta$-amyloid accumulation in Alzheimer's disease transgenic mice. $\mathrm{Neu}$ ron, 30, 665-676.

44) Atamna, H., Killilea, D. W., Killilea, A. N. and Ames, B. N. (2002) Heme deficiency may be a factor in the mitochondrial and neuronal decay of aging. Proc. Natl. Acad. Sci. U.S.A., 99, 14807-14812.

45) Namekata, K., Imagawa, M., Terashi, A., Ohta, S., Oyama, F. and Ihara, Y. (1997) Association of transferrin C2 allele with late-onset Alzheimer's disease. Hum. Genet., 101, 126-129.

46) Imagawa, M., Naruse, S., Tsuji, S., Fujioka, A. and Yamaguchi, H. (1992) Coenzyme $\mathrm{Q}_{10}$, iron, and vitamin $\mathrm{B}_{6}$ in genetically-confirmed Alzheimer's disease, Lancet, 340, 671.

47) Pratico, D., Uryu, K., Sung, S., Tang, S., Trojanowski, J. Q. and Lee, V. M. (2002) Aluminum modulates brain amyloidosis through oxidative stress in APP transgenic mice. FASEB J., 16, 11381140.

48) Kawahara, M., Kato-Negishi, M., Hosoda, R., Imamura, L., Tsuda, M. and Kuroda, Y. (2003) Brainderived neurotrophic factor protects neurotoxixity of cultured rat hippocampal neurons induced by aluminum maltolate. J. Inorg. Biochem. (in press). 